\author{
Urszula Glensk (D) https://orcid.org/0000-0003-1045-915X \\ Uniwersytet Wrocławski \\ urszula.glensk@uwr.edu.pl
}

Milan Lesiak (iD https://orcid.org/0000-0002-0405-0967

Uniwersytet Wrocławski

milan.lesiak@uwr.edu.pl

\title{
Mozaikowanie prawdy. Narracje quasi-faktyczne w reportażu literackim
}

\section{Mosaic of Truth: Quasi-factual Narratives in Literary Reportage}

Abstract: The article discusses the relation between the factography and the fiction in literary reportage. The text proposes the term of quasi-factual narrative, which describes a rhetorical figure typical for the documentary genres amplifying their descriptivity. Second category: factual narrative is an intentional distortion that is unauthorised in the reportage genre. The theoretical proposal referring back to the tradition of literary studies that dates back to the interwar period was discussed using the example of oeuvre of old and contemporary authors such as Wanda Melder, Melchior Wańkowicz, Hanna Krall, Anna Kaszuba-Dębska, Wojciech Jagielski and Anna Fryczkowska - the author of factual narrative.

Keywords: contemporary reportage, interwar reportage, quasi-factual narrative, factual narrative, literary fiction

Streszczenie: W artykule omówione zostały relacje między faktografią a fikcją w reportażu literackim. W tekście zaproponowany został termin narracja quasi-faktyczna, opisujący typową dla gatunków dokumentalnych figurę retoryczną, amplifikującą obrazowanie. Druga kategoria: narracja faktoidalna jest intencjonalnym i nieuprawnionym w pisarstwie reportażowym przekłamaniem. Propozycja teoretyczna, odnosząca się do tradycji literaturoznawczej sięgającej międzywojnia, została omówiona na przykładzie twórczości autorów dawnych i współczesnych, między innymi Wandy Melcer, Melchiora Wańkowicza, Hanny Krall, Anny Kaszuby-Dębskiej, Wojciecha Jagielskiego i Anny Fryczkowskiej, autorki narracji faktoidalnej.

Słowa kluczowe: reportaż współczesny, reportaż międzywojenny, narracja quasi-faktyczna, narracja faktoidalna, fikcja literacka 
W roku $2011 \mathrm{w}$ teoretycznej refleksji nad reportażem literackim nastąił punkt zwrotny. Rozgorzała wówczas wielka debata medialna, wykraczająca poza literaturoznawcze dyskusje o genologii. Dotyczyła prawdy i zmyślenia w literaturze faktu. Impulsem do sporu stała się książka Artura Domosławskiego Kapuściński non-fiction. Biograf postawił w niej tezę, że Ryszard Kapuściński przekręcał fakty, a jego twórczość reporterska jest pełna nieścisłości. Domosławski zajął się weryfikowaniem wybranych scen z pisarstwa Kapuścińskiego i starał się podważyć autentyzm relacji reportera. Jeździł w miejsca opisane przez reportera, szukał świadków, korzystał z uniwersum internetowego, aby sprawdzać informacje zapisane przez Kapuścińskiego 40 lat wcześniej w objętej dekolonizacyjną rewolucją Afryce. W swoim fact-checkingu Domosławski wziął pod uwagę wskazówki brytyjskiego antropologa Johna Ryle’a i jego sprostowania, choćby takie, że Sudan nie był jedynie kolonią brytyjską, ale obszarem tym zarządzali wspólnie Anglicy z Egipcjanami. Inny, podsunięty przez Ryle'a zarzut, dotyczył plemion Dinka i Nuer, które wbrew informacji Kapuścińskiego nie są wegetariańskie, ale jedzą również ryby i mięso. Jeszcze innym dowodem na "nieuzasadniony dramatyzm” i „przejaskrawienia pisarskie” reportera jest porównanie dziennika Jarda Boučeka z reportażem Kapuścińskiego. Razem obserwowali wojnę domową w Kongo, choć ich teksty powstały w różnym czasie ${ }^{1}$.

Domosławski kataloguje nieścisłości, ignorując podstawowy fakt, że uproszczenie, uogólnienie, metafora są typowymi elementami reportażu literackiego i stanowią pomost między ekspresją pisarską a próbą opisania realnego świata. Literatura non-fiction nie sprowadza się do zapisywania depesz informacyjnych jej istotą jest przedstawianie całościowego obrazu zdarzeń. Dokumentalista nie tylko respektuje znaczenie faktu, ale także bierze pod uwagę estetykę tekstu, dba o spójność narracji i kompozycji oraz - co ważne - panuje nad kryterium czytelności. Źle skonstruowane i przesycone nadmiarem faktów książki reportażowe nie znajdują większego uznania, co czasem przysłania inne ich walory (w takim zaułku znalazły się reportaże Usypać góry. Historie z Polesia Małgorzaty Szejnert czy Poznañ. Miasto grzechu Marcina Kąckiego).

Próba śledczego odczytania twórczości Ryszarda Kapuścińskiego przez Domosławskiego pokazała raczej, że w istocie niewiele było do podważenia, aczkolwiek teza postawiona przez biografa została podchwycona, prowokacja stała się częścią machiny promocyjnej, a publicyści masowych mediów deliberowali nad prawdziwością tekstów autora Cesarza (na przykład czy słynny piesek Lulu w istocie obsikiwał buty dworzan Hajle Sellasje). Chwyt marketingowy, polegający na wzbudzeniu sensacji i atmosfery demistyfikacji, odniósł skutek. Do dokumentalistyki Kapuścińskiego przylgnęly tezy o zmyślaniu, kłamstwie reportażowym, konfabulacjach. Dzisiejsi studenci kierunków humanistycznych nie

${ }^{1}$ Szczegółowo ten wątek biografii omawiają Beata Nowacka i Zygmunt Ziątek w książce Literatura non-fiction. Czytanie Kapuścińskiego po Domostawskim, Katowice 2013, s. 19-20. 
potrafią wiele powiedzieć o książkach pisarza, ponieważ ich nie znają, ale szybko kojarzą etykietę nierzetelności reportera.

Wskazanych przez Domosławskiego sensacji było więcej, bo obok niewierności wobec faktów biograf tropił jeszcze niewierność ideałom i niewierność małżeńską. Wszystkie te wątki przetoczyły się przez media głównego nurtu, przyniosły wielki rozgłos książce, wkrótce przetłumaczonej na osiem języków. Komentarzem tej sytuacji może być cytat z Sándora Máraia, który w lutym 1985 roku zanotował w swoim słynnym Dzienniku:

Pewien grabarz opublikował książkę pod tytułem Sekret Hawthorne'a. Twierdzi w niej, że ten wielki klasyk zeszłowiecznej literatury amerykańskiej cierpiał z powodu jakiejś kazirodczej tajemnicy. Dowodów nie ma żadnych, ale grabarz pomysłowo grupuje przypuszczenia, z których wynika, że pisarz miał kontakty seksualne z jedną z młodszych sióstr... Te pracowite hieny cmentarne nie spoczną, póki nie rozgrzebią przeszłości zmarłych sław. Już niewiele brakuje, a oskarżą o kazirodztwo bliźnięta w łonie matki².

Sąd nad reportażem spowodowany publikacją Domosławskiego pokazuje, że istnieje potrzeba powrotu do historyczno-literaturoznawczej refleksji nad obecnością kreacji i poetyki fikcjonalnej w reportażu. Na potrzeby artykułu te elementy obrazowania proponujemy nazwać narracją quasi-faktyczną, będącą przeciwieństwem opowieści faktoidalnej. Narracja quasi-faktyczna służy wzmocnieniu obrazowania i zalicza się do zasobu figur retorycznych pisarstwa faktograficznego, natomiast narracja faktoidalna jest rodzajem intencjonalnego przekłamania. Określenie to pochodzi od neologizmu „faktoid” użytego przez Normana Mailera, który w ten sposób nazwał „fakty nieistniejące przed ukazaniem się w czasopiśmie lub gazecie"3.

Punktem wyjścia do analizy elementów fikcjonalnych w reportażu musi być jednak podstawowe pytanie: w jakim stopniu w ogóle możliwe jest przekształcanie realnego doświadczenia w formę narracyjną? Czym jest transgresja zachodząca podczas przekładania faktu na tekst?

Badacze neuroscience twierdzą, że w pamięci utrwalają się jedynie obrazy zdarzeń, które już w procesie obserwacji i zapamiętywania ulegają mimowolnym przetworzeniom ${ }^{4}$. Jeśli dodać do tego punkt obserwacji świadka, wówczas dodatkowo maleje szansa na pełne rozeznanie i obiektywne odtwarzanie zdarzeń. Kolejnym etapem redukcji wiedzy o realnym doświadczeniu jest proces zapamiętywania

2 S. Márai, Dziennik 1977-1989, wybór, tłum., oprac., przypisy i posłowie T. Worowska, Warszawa 2020, s. 314.

${ }^{3}$ D. Marsh, A Factoid Is Not a Small Fact. Fact, „The Guardian”, 17.01.2014, https://www. theguardian.com/media/mind-your-language/2014/jan/17/mind-your-language-factoids, dostęp: 17.06.2021; E.R. Kandel, J.H. Schwartz, Th.M. Jessell i in., Principles of Neural Science, wyd. 5, McGraw-Hill-New York 2012.

${ }^{4}$ E.R. Kandel, James H. Schwartz, Thomas M. Jessell i in., dz. cyt., s. 65. 
i pamięci, która także ulega atrofii. Ponadto do zniekształceń obrazu trzeba jeszcze dodać nieuczciwość intencji i relacji świadka. Konkluzja wydaje się nieunikniona: obiektywna wiedza o faktach jest nieosiągalna. Nieistnienie czystych faktów pamięci skutkuje niemożnością ich odtworzenia i zapisania w formie narracyjnej. Możemy jedynie zbliżyć się do prawdy, jednak bez szans na jej osiągnięcie.

Te ograniczenia pisarstwa dokumentalnego zauważył już Aleksander Wat, pierwszy konsekwentny teoretyk reportażu w Polsce. Przy okazji promowania politycznej idei Nowego Lefu do istotnych przekształceń poznawczych włączał również predyspozycje samego autora reportażu: „»Fakt « nie jest czymś utrwalonym i jednoznacznym (...), jest zespołem najrozmaitszych stosunków, tak, że pisarz, opisujący określony fakt czy proces, zależnie od swojej klasowej psychoideologii widzi i opisuje te, a nie inne stosunki"s. Wat nie mylił się, wskazując na istnienie relacji między postrzeganiem i pisaniem a tożsamością samego autora. Redaktor „Miesięcznika Literackiego” nazywał promowany w czasopiśmie gatunek faktomontażem, czym podkreślał rolę reportera jako kogoś, kto jedynie układa fakty.

Refleksja gatunkowa nad reportażem wyrastała początkowo z doświadczenia dziewiętnastowiecznej literatury realistycznej, a zatem z pytania o możliwość uchwycenia realnego kształtu rzeczywistości w tekście literackim. Pytania o konwencję pisarstwa faktograficznego wiązane były z kwestią realizmu w literaturze, mniej uwagi poświęcano natomiast relacji między sprawozdaniem dziennikarskim a reportażem literackim. Przykładem takiego rozumienia realizmu w literaturze są Zaklęte rewiry Henryka Worcella, powieści wydanej z roku 1936 i natychmiast uznanej za faktograficzną, wyrastającą z autobiograficznych doświadczeń autora.

W „Miesięczniku Literackim” lansowano pogląd, że należy pragmatycznie wykorzystać reportaż w rywalizacji politycznej, pokazując w faktomontażach niedolę proletariatu i perspektywę buntu. Nie ukrywano propagandowego charakteru nowego gatunku. Międzywojenni krytycy zauważyli tę tendencję. Największy sceptycyzm manifestował Ignacy Fik, pisząc, że „mimo (...) pozorów autentyczności i prawdomówności (założenie reportażu) żaden inny rodzaj literacki nie nadaje się tak doskonale do przedstawiania - nieprawdy, jak reportaż"6. Pozory prawdy skutecznie zasłaniają nieprawdę, co zauważają także współcześni badacze fake newsów, podkreślający, że najbardziej skuteczna dezinformacja powstaje wtedy, gdy przekaz łączy elementy weryfikowalnej rzeczywistości z fałszem.

W archiwum teorii literatury jest jeszcze jeden ważny wątek, który leżał u źródeł refleksji nad reportażem. Melchior Wańkowicz w manifeście Oposzerzenie konwencji reportażu twierdził, że „komponent artystyczny” $i$ „wyobraźnia” leżą u podstaw sukcesu pisarza dokumentalisty, a podział między reportażystą a powieściopisarzem

${ }^{5}$ A. Wat, Pisma zebrane. Publicystyka, zebranie, oprac., przypisy, posłowie i indeks P. Pietrych, Warszawa 2008, s. 223 (pierwodruk: Reportaż jako rodzaj literacki, „Miesięcznik Literacki” 1930, nr 7).

${ }^{6}$ I. Fik, O reportażu, „Gazeta Artystów”, 29.09.1934, nr 5; zob. też: tenże, Wybór pism krytycznych, oprac. i wstęp A. Chruszczyński, Warszawa 1961, s. 3. 
da się sprowadzić do różnicy „między malarzem a mozaikarzem” - ten drugi układa z fragmentów, którymi dysponuje. Jednocześnie Wańkowicz, powołując się na Włodzimierza Maciąga, przyjmuje zasadę „prymatu konstrukcji ogólnej”, która dominuje nad „informacją szczegółową”. W rezultacie reporter daje sobie prawo do łączenia wątków dokumentalnych w taki sposób, aby uzyskać atrakcyjną spójność narracji. W przywołanym manifeście Wańkowicz odsłania tajniki warsztatowe. Uznaje za akceptowalne scalanie kilku postaci w jedną, bardziej wyrazistą i atrakcyjną dla czytelnika. Obrazuje tę technikę - mozaikarza - przykładem z własnego reportażu: Droga do Urzędowa $a^{8}$, w którym opisał komendanta garnizonu w Tarencie, tworząc go z trzech realnych generałów. Opisany dowódca próbował bronić swojego wizerunku w prasie. Bezskutecznie.

Podobnej techniki Wańkowicz użył w reportażu Tworzywo o polskich emigrantach w Kanadzie. Lubiący statystykę pisarz wylicza, że zgodnie z koncepcją tej panoramicznej opowieści musiałby zmieścić w niej 288 elementów pochodzących z różnych życiorysów. I uzasadnia:

tymczasem w każdym życiorysie jest jakiś punkt szczytowy, a reszta szara. A więc jeden z ludzkich prototypów Tworzywa miał w zaraniu wóz Drzymały i już potem nic. Inny nie reprezentował nic ciekawego w sensie dokumentarnym, póki nie znalazł złota. Jeden uciekł z Polski spod szubienicy, a potem w Kanadzie miał szare życie, ale natomiast jego syn, jako lotnik kanadyjski, został zestrzelony nad powstańczą Warszawą (...). W pogoni za prawdą dosłowną musiałbym albo zajmować się losem każdego człowieka od początku do końca - na to trzeba całych tomów, albo też wziąć z każdego życia moment najciekawszy9

Dokumentalista przyznawat, że zajmuje się zbieraniem wątków i dopasowywaniem ich do siebie w taki sposób, aby ukazywały spójną całość, zdolną pokazać „prawdę generalną" ${ }^{10}$, ale niekoniecznie „prawdę literalną". Tego rodzaju zabiegi, co też przypomina Wańkowicz, wykorzystywał Ksawery Pruszyński w swoich ostatnich, beletryzowanych książkach: Trzynaście opowieści i Karabela z Mesche$d u$. Rozmowa w szpitalu w roku 1944 i inna z objętej wojną domową Hiszpanii zostały scalone w jedną i wpisane do historii o Narviku, relacjonującej bitwę z początku drugiej wojny.

Reportażyści, wypowiadający się o technikach gatunkowych, wskazywali raczej na konwergencję gatunkową, a nie ścisłe oddzielanie beletrystyki od literatury faktu. Argumentem była dla nich konieczność tekstualizacji, zapisania doświadczenia w formie literackiej, spełniającej oczekiwania czytelnika i respektujące

${ }^{7}$ M. Wańkowicz, O poszerzenie konwencji reportażu [w:] tegoż, Od Stotpców po Kair, wybór, układ i przypisy S. Kozicki, Warszawa 1971, s. 7.

${ }^{8}$ Tenże, Droga do Urzędowa, Warszawa 1989.

${ }^{9}$ Tamże, s. 14.

${ }^{10}$ Tamże. 
jego ograniczenia poznawcze. Utrzymywanie linii demarkacyjnej między literaturą fikcjonalną a prozą dokumentalną zostało podważone również w dyskusjach teoretycznoliterackich. Analiza stanowiska badaczy tekstów autentystycznych prowadzi Pawła Zajasa do tezy o erozji opozycji między fikcyjnym i niefikcyjnym i uznania, że „Zwrot narratywistyczny uwydatnił konstrukcyjny charakter procesów poznawczych, zapośredniczenie dostępu do nagich faktów i nieuniknioną beletryzację doświadczenia"11.

Narracja quasi-faktyczna polega na łączeniu scen, dialogów, kompilowaniu postaci i - w końcu - na eseizacji, która wskazuje interpretację i może mieć perswazyjny wpływ na odbiorcę. Część z rozpoznań reporterskich przenika do tekstu w formie dyskursywnej i nie wszystkie zasłyszane i rozpoznane przez reportera historie zostają wpisane w relacje świadków czy cytaty lub przytoczenia z wyszukanych dokumentów. W ten sposób do literatury dokumentalnej włączane są elementy kreacji pisarskiej. Te zabiegi mogą być też różnie oceniana przez krytyków, ale są wykorzystywane w prozie non-fiction znacznie częściej, niż zostaje to wykazane przez samych pisarzy i recenzentów.

Kilka charakterystycznych przykładów z różnych epok literackich. W międzywojniu popularność zyskały reportaże Wandy Melcer, pierwotnie publikowane w „Wiadomościach Literackich”, a później w jej książkach w rozbudowanej wersji. W cyklu relacji reportażowych z Nalewek Czarny Ląd Warszawa Melcer szczegółowo opisała Szlomową Blajman mieszkającą przy ulicy Gęsiej. Czytelnik mógł się dowiedzieć, że bohaterka ta handluje papierowymi kwiatami, ma troje dzieci i niezbyt rygorystycznie przestrzega żydowskiej tradycji, choćby dlatego, że nie nosi peruki, chociaż jest mężatką. Pani Blajman odgrywa rolę przewodniczki - oprowadza reporterkę po mykwie, wyjaśnia panujące tam obyczaje. Opowieść o życiu codziennym mniejszości żydowskiej w Warszawie wzbudziła poważne zastrzeżenia czytelników i krytyków, na które Melcer próbowała odpowiedzieć we wstępie do książkowego wydania swoich reportaży. Wyjaśniała:

mogłabym wymienić dla każdego reportażu kilku specjalistów, a więc adwokatów, lekarzy, pedagogów, którzy nie tylko towarzyszyli mi w moich wędrówkach, ale po napisaniu przeglądali to, co napisałam (...). Nie chcę się bronić, zdaję sobie sprawę z niedoskonałości mojej pracy, a wyrażając wielką wdzięczność moim łaskawym współpracownikom i informatorom, rozumiem, że mogłam niedokładnie z ich wskazówek skorzystać. Ale to jedno zaznaczam wyraźnie: Szlomowa Blajman jest postacią wymyśloną, właściwie skompilowaną z żydówek, z którymi mogłam się podczas moich wędrówek zapoznać. Wszystkie nazwiska i adresy, podane w moich reportażach są zmyślone, prawdziwe są tylko fakty ${ }^{12}$.

${ }^{11}$ P. Zajas, Jak świat prawdziwy stat się bajką. O literaturze niefikcjonalnej, Poznań 2011, s. 13.

${ }^{12}$ W. Melcer, Czarny Ląd Warszawa, Warszawa 1936, s. 12-13. 
Ta deklaracja została złożona pod wpływem rzeczowej krytyki tekstów Melcer, które były odbierane jako jawnie stronnicze, niechętne ortodoksyjnej społeczności żydowskiej (tak też brzmią obecnie). Gdyby relacja Melcer nie wzbudziła takich negatywnych emocji, zapewne krytycy i czytelnicy aż tak wnikliwie nie śledziliby źródeł opowieści i nie dociekaliby, czy ktoś taki jak Blajman w rzeczywistości istnieje. Zresztą ustalenie, że kwiaciarka jest postacią wykreowaną, było dość łatwe, ponieważ mieszkańcy ulicy Gęsiej dobrze się nawzajem znali. Szukano argumentów, które pokazałyby tendencyjność Melcer, przyglądano się szczegółom, które najłatwiej można falsyfikować.

Inny przykład quasi-faktyczności można wskazać u Hanny Krall, autorki przykładającej ogromną wagę do autentyzmu relacji reporterskiej. Jednak i ona pod wpływem reakcji czytelników zmieniła w swojej słynnej książce jeden ze szczegółów dotyczący przedwojennego życia Mordechaja Anielewicza i jego matki. Pisarka przyznała:

Napisałam: „malowała skrzela...”. Kilka lat temu w Zdążć przed Panem Bogiem napisałam, że to synowi swojemu kazała malować skrzela, ale podniósł się taki zgiełk, tak wielu ludzi oburzyło się na mnie i mnie strofowało, że postanowiłam nie powtórzyć już więcej tego błędu. Oczywiście, to ona, handlarka ryb z Solca, nie jej bohaterski syn, malowała skrzela i sprzedawała następnego dnia wczorajszy towar... ${ }^{13}$

W pierwszej wersji książki malowanie rybich skrzeli zostało przypisane Anielewiczowi, ponieważ ubarwiało to także jego portret.

Jednocześnie Krall w innym miejscu deklaruje: „reportaż literacki absolutnie nie może być fikcją. Jeśli przedostaje się do niego fikcja, to już nie jest reportaż” ${ }^{14}$, a jeszcze dalej: „jestem niewolniczo przywiązana do faktów”'15 i wyjaśnia: „mój szacunek dla faktów, bo to jest chyba właśnie szacunek, wynika z tematyki, którą się zajmuję"16.

Wierność faktograficzna jest trudna do osiągnięcia nawet w wypadku reporterów programowo respektujących autentyk i głoszących koncepcje gatunku jako swoistej formy dziennikarskiej. W twórczości Krall doprowadziło to zresztą do bardzo oszczędnych opisów, pełnych niedopowiedzeń i elips, szczególnie w książkach odtwarzających historie holokaustowe, w których opowiedziane mają zostać jedynie zdarzenia przekazane w relacjach świadków lub odnalezione w dokumentach. Tego rodzaju deklaracje pisarskie są nieczęste. Spośród uznanych

${ }^{13}$ H. Krall, Smutek ryb, Warszawa 2020, s. 12-13. Pierwodruk cytowanego fragmentu pochodzi z roku 1983.

${ }^{14}$ Reporterka. Rozmowy z Hanna Krall, wybór, kompozycja, uzupełnienia i dokumentacja J. Antczak, Warszawa 2015, s. 66.

15 Tamże, s. 206.

16 Tamże, s. 67. 
reporterów średniego pokolenia składają je Magdalena Grzebałkowska i Cezary Łazarewicz, co wydaje się niebezpodstawne.

Tymczasem elementy narracji quasi-faktycznej mogą zostać niezauważone przez czytelnika w przypadku przekształcenia szczegółów czy kompilacji postaci. Są natomiast łatwo zauważalne w opisach wyobrażeniowych, w których pisarz dokumentalista odtwarza jakiś brakujący element. Charakterystycznym przykładem takiej opowieści jest fragment Szachinszacha Ryszarda Kapuścińskiego, odtwarzający wędrówkę przez pustynię zabójcy szacha i eskortującego go strażnika. Działo się to w roku 1896, nikt nie mógł opowiedzieć reporterowi, gdzie dokładnie siadali, kto dawał im jedzenie i czy ze smakiem - jeśli w ogóle - zjadali suszoną szarańczę. Sugestywny obraz został zrekonstruowany na podstawie wiedzy o historii obyczaju, podpowiadającej, że ludy pustynne pod koniec XIX wieku odżywiały się szarańczą, chroniły w glinianych lepiankach. Reszta została uruchomiona przez wyobraźnię pisarza. Czytelnik może to łatwo zauważyć, jeśli tylko w trakcie lektury podda analizie kolejne elementy opisu.

Przykłady tego rodzaju poetyki można mnożyć. Chętnie sięgają po nią biografowie. Anna Kaszuba-Dębska w książce Bruno. Epoka genialna szkicuje:

sierpniowej nocy roku 1938 Bruno Schulz siedzi przy ludwikowskim stoliku i wraz z wiernym kompanem Georges'em Rosenbergiem przysłuchuje się dźwiękom cygańsko-słowiańskiego jazzu. Przygląda się srebrnym zastawom, sięga po kielich, butelki szampana chłodzą się w naczyniach wypełnionych lodem. Degustuje wykwintne trunki, obserwuje tańczące na parkiecie pary, poznaje świat nocnego Montmartre'u, kuszący podejrzanymi rozkoszami ${ }^{17}$.

W istocie Schulz przebywał w tym czasie w Paryżu, znał Rosenberga. Reszta elementów jest domniemaniem, zbliżoną do prawdopodobieństwa scenerią: styl mebli, rodzaj nakryć i trunków, nocne życie w artystowskiej dzielnicy miasta. Trudno dać jednak wiarę, że w paryskim lokalu grano w latach trzydziestych cygańsko-słowiański jazz. W Europie Środkowej muzyka ta dopiero stawała się modna i poddawana była lokalnej adaptacji dźwiękowej. Balansowanie między prawdą doświadczenia a materią tekstu jest istotą dokumentalizmu.

W tworzeniu portretów zbiorowych znaną i stosowaną techniką jest łączenie postaci. Czasem informacje o tego rodzaju zabiegu są wpisywane w tekst reportażu lub antycypują narrację. Wojciech Jagielski książkę Nocni wędrowcy poprzedza notą:

jest to opowieść prawdziwa, podobnie jak prawdziwe jest miasteczko Gulu, w którym się ona rozgrywa. Prawdziwi są też bohaterowie opowieści: opętani przez duchy Joseph Kony, stary Severino (...), a także dzieci, z których nocami duchy

${ }^{17}$ A. Kaszuba-Dębska, Bruno. Epoka genialna, Kraków 2020, s. 69-70. 
czynią okrutnych i bezlitosnych partyzantów. Nora, Samuel i Jackson na potrzeby tej opowieści stworzeni zostali z kilku rzeczywistych postaci ${ }^{18}$.

Czy tego rodzaju informacja podważa gatunkowość książki Jagielskiego? Czy gdyby nie została zamieszczona, czytelnik miałby szansę ocenić, który z chłopców mieszkających w ośrodku w Ugandzie jest postacią autentyczną, precyzyjnie odwzorowaną, a który został wykreowany w rezultacie obserwacji i wyobraźni autora?

Podobnym zabiegom stylistycznym i fikcjonalnym podlegają dialogi. W wielu reportażach tworzone są one na zasadzie prawdopodobieństwa. Przykład dialogu domniemanego można uchwycić w biografii Komendant. Życie Salomona Morela Anny Malinowskiej, w której autorka opisuje atmosferę na lubelskiej wsi podczas okupacji:

Do Geni od czasu do czasu przychodzą z lasu. - Dajcie, gospodyni, jedzenia. A może wódkę macie? - śmieją się.

Dajcie spokój. Męża mi zabrali, biedna wdowa jestem - Genia daje trochę chleba i ziemniaków. Byle tylko poszli, byle był spokój ${ }^{19}$.

Trudno o bardziej schematyczną rozmowę, która w oczywisty sposób jest reprezentacją typowej okupacyjnej sytuacji. Autorka mogłaby wyrazić ją opisowo, ale dialogi są rodzajem uatrakcyjnienia tekstu. Dopracowane, czy raczej odpowiednio zmontowane, rozmowy są ważnym elementem twórczości Mariusza Szczygła, który w przywoływane dialogi wpisuje kontrapunkty, paradoksy, pointy i aforyzmy. Poziom estetyzacji wskazuje, że są to rozmowy „powycinane” lub rozbudowane w taki sposób, aby miały nie tylko walory informacyjne, ale przede wszystkim artystyczne.

$\mathrm{Na}$ wiarygodność tekstu reportażowego wpływają różne elementy tworzące opowieść - znaczenie mają zarówno prawdopodobieństwo i spójność; zróżnicowanie stylistyczne dialogów; obiektywizm przedstawień; sekwencje faktograficzne; wpisane w tekst cytaty z prac historycznych, antropologicznych, socjologicznych czy religioznawczych; a także pozycja i wiarygodność autora oraz jego wcześniejszy dorobek.

Popularność literatury non-fiction manifestuje się liczbą wydawanych w tym gatunku publikacji, obecnością książek reportażowych na długich i krótkich listach nagród literackich, tworzeniem dokumentalnych serii wydawniczych. Nieoczekiwanie pojawiła się literatura imitująca reportaż. Przykładem takiej hybrydycznej formy, którą trzeba uznać za narrację faktoidalną, jest Równonoc Anny Fryczkowskiej, opublikowana w serii Na F/aktach. Pierwsze strony sugerują czytelnikowi, że opowieść jest relacją z autentycznych wydarzeń kryminalnych. Nota wprowadzająca podkreśla dziennikarskie dochodzenie: „Straty,

${ }^{18}$ W. Jagielski, Nocni wędrowcy, Warszawa 2009, s. 6.

19 A. Malinowska, Komendant. Życie Salomona Morela, Warszawa 2020, s. 15. 
21 marca 1998, mama Szymona”, a kolejne strony zawierają obszerne przytoczenia z komunikatów policyjnych, informujących o chłopcach zaginionych w latach dziewięćdziesiątych XX wieku. Początkowa część książki zawiera rozmowy z matkami zaginionych dzieci i robi wrażenie, że są to zapisy realnych zwierzeń cierpiących kobiet. Wraz z kolejnymi stronami opowieść staje się coraz mniej wiarygodna i coraz bardziej absurdalna, choćby przez mgliście wskazanego sprawcę porwań. Na końcu tego niby-reportażu, na stronie redakcyjnej, pojawia się nota: „Zarys fabuly książki Równonoc jest oparty na prawdziwych zdarzeniach. Trzeba jednak pamiętać, że tekst nie jest reportażem, tylko dziełem fikcji literackiej. Nie należy go traktować jak dokumentu" ${ }^{20}$. Zastrzeżenia budzi miejsce wskazania tej informacji. Gdyby pojawiła się na początku, czytelnik od razu miałby szansę zorientować się, że ma do czynienia z narracją faktoidalną, tymczasem udawany autentyzm utrzymuje przy lekturze odbiorców ciekawych dalszego ciągu dramatycznej historii. Pozorowanie reportażu do pewnego momentu przysłania słabość książki Fryczkowskiej. Ostatecznie autorka i wydawcy zastrzegli, że nie jest to opowieść o prawdziwych zdarzeniach, a jedynie fabuła, ponieważ rzecz dotyczy dość znanej historii i relatywnie łatwo bytoby dokonać fact chekingu.

Narracje faktoidalne nie zawsze są możliwe do zweryfikowania, szczególnie gdy zostały napisane z dużym efektem prawdopodobieństwa i opowiadają o osobistych przeżyciach bohaterów, których tożsamość została ukryta pod pseudonimem, a w narracji brakuje atrybutów miejsca i czasu. Czytelnik nie potrafi rozstrzygnąć, w jakim stopniu reporter zachowuje pakt referencjalny, jeżeli nie zostanie o tym poinformowany.

Czasem o klasyfikacji gatunkowej decyduje miejsce publikacji. Tak jest w wypadku tekstu W'siekty pies Wojciecha Tochmana. W literacko wystylizowanej opowieści anonimowy ksiądz wygłasza kazanie, które jest jednocześnie wyznaniem jego własnych grzechów. W konkluzji pojawia się wyjaśnienie: „Wszystko, co tu powiedziałem, jest prawdą: mam trzydzieści trzy lata, mieszkam w Polsce, jestem księdzem, jestem homoseksualistą, jestem zakażony. Powinienem rzucić sutannę i odejść. Ale nigdy nie odejdę. I tej homilii nigdy nie wygłoszę, choć myślę o niej codziennie"21. Nigdy niewypowiedziane słowa są zapisem faktów psychicznych. Jeśli zgodzimy się, że W'sciekty pies jest reportażem, to co zrobić z wielką powieścią realistyczną, w której równie istotną rolę odgrywa reprezentacja doświadczenia? Czy o Émile’u Zoli powiemy, że był reporterem? A czy o Wojciechu Jagielskim orzekniemy, że jest powieściopisarzem, choćby po przeczytaniu Wszystkich wojen Lary?

Narracja faktoidalna pozoruje opowieść o realnym doświadczeniu, ale istnieje jedynie w materiale tekstowym i nie ma odpowiednika w rzeczywistości. Czasem może też służyć celowej manipulacji i jest elementem propagandy.

20 A. Fryczkowska, Równonoc, Na F/aktach, Warszawa 2018, s. 286 (strona redakcyjna).

21 W. Tochman, Wściekty pies [w:] tegoż, Bóg zaptać, Wołowiec 2010, s. 234. 
Należy także podkreślić, że nieintencjonalne błędy faktograficzne, które zdarzają się reportażach, nie czynią jeszcze z tekstu narracji faktoidalnej. Przykładem pomyłki, która nie obniża dokumentacyjnej wartości całego tomu, jest błędnie podana kwota w pierwszym wydaniu książki Sendlerowa w ukryciu Anny Bikont. Suma przeznaczona przez rząd emigracyjny w Londynie na „Żegotę”, Radę Pomocy Żydom, w marcu 1943 roku wynosiła 270 tysięcy złotych, podczas gdy w książce pojawia się kwota 270 milionów złotych ${ }^{22}$. Uważny czytelnik mógł ten błąd redakcyjny wychwycić, jeśli przeczytał przypisy. Cenna książka Bikont nie traci wiarygodności z powodu pomyłki w jednej z setek pojawiających się w niej liczb.

„Gatunki zmącone” wymykają się ostrym kryteriom genologicznym. Próby przełamywania konwencji, szczególnie w literaturze XX wieku, były podejmowane z rozmystem, wkalkulowane w ryzyko rozminięcia się z przyzwyczajeniami i oczekiwaniami czytelników. Pod koniec lat pięćdziesiątych ubiegłego stulecia Simone de Beauvoir, swoim wysokim i niekoniecznie przyjemnym w odbiorze głosem, snuła podczas wykładu na Sorbonie rozważania nad powieścią i zadawała pytanie - czy powieść jest wciąż możliwa ${ }^{23}$ Kontestowała gatunek. W tym samym czasie Melchior Wańkowicz upominał się o rolę reportażu jako pisarstwa pogranicza ${ }^{24} \mathrm{i}$ twierdzit, że celem dokumentalistyki literackiej jest uchwycenie „prawdy generalnej” (general truth), nawet za cenę swobodnego komponowania „prawdy literalnej" (literary truth). Idee autora Sztafety wpłynęły na kształtowanie gatunku łączącego sprawozdawczość z literaturą. Koncepcje Wańkowicza zyskały na znaczeniu w latach siedemdziesiątych XX wieku, kiedy autorzy rozwijali poetykę wielkiej aluzji, która w historii literatury nazwana została „polską szkołą reportażu" i oznaczała ucieczkę przed cenzurą. Uogólnienia, kompilacja zdarzeń i życiorysów, elementy rozpoznawalnej fikcji zadomowiły się w wielkim reportażu. Także współcześnie narracje quasi-faktyczne należą do zasobu figur retorycznych prozy dokumentalnej. Tej konwencji nie zmieni nawet pozorna łatwość internetowego weryfikowania faktów.

Reportaż dotyka doświadczenia, ale nie potrafi odtworzyć go dosłownie. Reszta jest literaturą.

\section{Bibliografia}

Bikont A., Sendlerowa w ukryciu, Wołowiec 2017.

Fik I., Wybór pism krytycznych, oprac. i wstęp. A. Chruszczyński, Warszawa 1961.

Fryczkowska A., Równonoc, Na F/aktach, Warszawa 2018.

${ }^{22}$ A. Bikont, Sendlerowa w ukryciu, Wołowiec 2017, s. 149.

${ }^{23}$ S. Sontag, Odrodzona. Dzienniki, t. 1: 1947-1963, przemowa D. Rieff, ttum. D. Żukowski, Kraków 2012, s. 241.

${ }^{24}$ Por. M. Wańkowicz, Prosto od krowy, Warszawa 1965, s. 37-57. 
Jagielski W., Nocni wędrowcy, Warszawa 2009.

Jagielski W., Wszystkie wojny Lary, Kraków 2015.

Kandel E.R., Schwartz J.H., T.M. i in., Principles of Neural Science, wyd. 5, McGraw-Hill-New York 2012.

Kaszuba-Dębska A., Bruno. Epoka genialna, Kraków 2020.

Kącki M., Poznań. Miasto grzechu, Wołowiec 2018.

Krall H., Smutek ryb, Warszawa 2020.

Malinowska A., Komendant. Życie Salomona Morela, Warszawa 2020.

Márai S., Dziennik 1977-1989, wybór, tłum., oprac., przypisy i posłowie T. Worowska, Warszawa 2020.

Marsh D., A Factoid Is Not a Small Fact. Fact, „The Guardian”, 17.01.2014, https:// www.theguardian.com/media/mind-your-language/2014/jan/17/mind-your-language-factoids, dostęp: 2.10.2021.

Melcer W., Czarny Ląd Warszawa, Warszawa 1936.

Nowacka B., Ziątek Z., Literatura non-fiction. Czytanie Kapuśsińskiego po Domostawskim, Katowice 2013.

Pruszyński K., Karabela z Meschedu, Warszawa 1995

Pruszyński K., Trzynaście opowieści, Warszawa 1974.

Reporterka. Rozmowy z Hannq Krall, wybór, kompozycja, uzupełnienia oraz dokumentacja J. Antczak, Warszawa 2015.

Sontag S., Odrodzona. Dzienniki, t. 1: 1947-1963, przemowa D. Rieff, tłum. D. Żukowski, Kraków 2012.

Szejnert M., Usypać góry. Historie z Polesia, Kraków 2015.

Tochman W., Bóg zaptać, Wołowiec 2010.

Wańkowicz M., Droga do Urzędowa, Warszawa 1989.

Wańkowicz M., Od Stolpców po Kair, wybór, układ i przypisy S. Kozicki, Warszawa 1971.

Wańkowicz M., Prosto od krowy, Warszawa 1965.

Wat A., Pisma zebrane. Publicystyka, zebranie, oprac., przypisy, posłowie i indeks P. Pietrych, Warszawa 2008.

Zajas P.,Jak świat prawdziwy stat się bajką. O literaturze niefikcjonalnej, Poznań 2011. 